\title{
Pengaruh Kemampuan Membaca Pemahaman dan Minat Belajar terhadap Kemampuan Menulis Cerita Pendek
}

\author{
Marinan \\ Fakultas Pascasarjana, Universitas Indraprasta PGRI \\ Jalan Nangka No. 58 C/TB. Simatupang, Tanjung Barat, Jakarta Selatan 12530 \\ marinannn80@gmail.com
}

\begin{abstract}
The purpose of the study is to see the effect of students reading comprehension and learning interests toward the ability to write short stories. The method of the research is a descriptive survey using some samples from several populations. Some questionnaires are used for data collection. The research sample consists of four (4) classes from two (2) Private Junior High School namely SMP PGRI 338 and MTs Daarussalam in Tangerang City. The result of the research shows that; 1). There is a collectively significant effect of the effect of students reading comprehension and learning interests toward the ability to write a short story, of the Private Junior high school students in Tangerang City. The significant effect was shown by the score of Sig. $=0,005<0,05$ and F0 = 5,744 . Both variables, the students reading comprehension and learning interests had given a contribution of $13 \%$ to the ability to write short stories. 2). There is a significant effect of students reading comprehension toward the ability to write short stories of private Junior High school students in Tangerang city. The significant effect was shown by the score of Sig. $=0,010<0,05$ and $\mathrm{t} 0=2,645$. The students reading comprehension variable had given a contribution to the ability to write short stories of $7,24 \% .3$ ). There is a significant effect of learning interests toward the ability to write short stories of the Private Junior High School students in Tangerang City. The significant effect was shown by the score of Sig. $=0,019<0,05$ and $\mathrm{t} 0=2,387$. This variable had given a contribution to the ability to write short stories of $5,74 \%$.
\end{abstract}

Keywords: students reading comprehension, learning interests, and short stories writing

\begin{abstract}
Abstrak
Tujuan dari penelitian ini adalah untuk mengetahui Pengaruh kemampuan membaca pemahaman dan minat belajar terhadap Kemampuan Menulis cerita pendek. Metode Penelitian yang digunakan adalah metode survey deskriptif yaitu suatu metoda penelitian yang mengambil sampel dari suatu populasi dan menggunakan kuesioner sebagai alat pengumpulan data. Jumlah sampel yang diambil sebanyak 4 kelas dari 2 sekolah yaitu SMP PGRI 338 dan MTs Daarussalam Kabupaten Tangerang. Hasil penelitian ini menunjukkan bahwa: 1). Terdapat pengaruh yang signifikan kemampuan membaca pemahaman dan minat belajar secara bersama-sama terhadap kemampuan menulis cerita pendek siswa SMP Swasta Kabupaten Tangerang. Hal ini dibuktikan dengan perolehan nilai Sig. $0,005<0,05$ dan $F_{\text {hitung }}=5,744$ Secara bersama-sama variabel kemampuan membaca pemahaman dan minat belajar memberikan kontribusi sebesar $13 \%$ terhadap variabel kemampuan menulis cerita pendek. (2) terdapat pengaruh yang signifikan kemampuan membaca pemahaman terhadap kemampuan menulis cerita pendek siswa SMP Swasta Kabupaten Tangerang. Hal ini dibuktikan dengan perolehan nilai Sig. $0,010<0,05$ dan $t_{\text {hitung }}=2,645$. Kontribusi yang diberikan variabel membaca pemahaman terhadap kemampuan menulis cerita pendek sebesar $7,24 \%$. (3) terdapat pengaruh yang signifikan minat belajar terhadap kemampuan menulis cerita pendek siswa SMP Swasta Kabupaten Tangerang. Hal ini dibuktikan dengan perolehan nilai Sig. 0,019<0,05 dan thitung $=2,387$. Variabel minat belajar ini memberikan kontribusi kepada peningkatkan kemampuan menulis cerita pendek siswa sebesar $5,74 \%$.
\end{abstract}

Kata Kunci: membaca pemahaman siswa, minat belajar, dan menulis cerita pendek 


\section{PENDAHULUAN}

Menulis punya peran yang sangat penting bagi manusia karena merupakan salah satu sarana untuk berkomunikasi sama seperti berbicara. Menulis adalah keterampilan berbahasa dalam konteks komunikasi tidak langsung. Menulis juga suatu kegiatan yang memerlukan cara berpikir yang beraturan atau terpola dalam bentuk bahasa tulis. Kegunaan menulis sangat banyak sekali, seperti mencatat, merekam, melaporkan, meyakinkan, menginformasikan, dan memengaruhi pembaca. Tentunya kegunaan tersebut dapat dicapai jika seseorang mampu mengorganisir ide dan gagasan dengan baik secara tertulis, lancar, dan komunikatif. Dalam kegiatan pembelajaran menulis siswa perlu diberi contoh tulisan yang baik dan benar. Contoh tersebut dapat diberikan melalui kegiatan membaca.

Dengan tingkat membaca pemahaman yang baik, siswa akan memahami suatu bacaan. Dengan pemahaman yang baik maka siswa akan mampu menyerap contoh-contoh cerita pendek yang diberikan oleh gurunya. Dengan contoh tersebut siswa akan memiliki bahan untuk menulis suatu cerita pendek. Dengan Kemampuan membaca pemahaman, siswa akan terarah untuk memahami kaidahkaidah penulisan certita pendek.

Pentingnya kemampuan membaca pemahaman dalam membaca cerita pendek tentu saja harus dijadikan fokus bagi guru dalam pembelajaran bahasa Indonesia, khususnya dalam kegiatan belajar menulis cerita pendek. Dengan kemampuan membaca pemahaman dan minat belajar akan mendorong siswa untuk mau secara terus-menerus berlatih menulis cerita pendek. Dengan seringnya melakukan kegiatan latihan maka kemampuan menulis cerita pendek akan diperoleh pula. Atas dasar uraian inilah peneliti tertarik untuk mengadakan suatu penelitian seberapa besar pengaruh kemampuan membaca pemahaman dan minat belajar terhadap kemampuan menulis cerita pendek yang penelitiannya akan dilakukan pada siswa SMP Swasta di Kabupaten Tangerang. Rumusan masalah dalam penelitian ini adalah apakah terdapat pengaruh kemampuan membaca pemahaman dan minat belajar secara bersama-sama terhadap kemampuan menulis cerita pendek siswa SMP Swasta di Kabupaten Tangerang? Apakah terdapat pengaruh kemampuan membaca pemahaman terhadap kemampuan menulis cerita pendek siswa SMP Swasta di Kabupaten Tangerang? Apakah terdapat pengaruh minat belajar terhadap kemampuan menulis cerita pendek siswa SMP Swasta di Kabupaten Tangerang?

Adapun tujuan dari penelitian ini meliputi pengaruh kemampuan membaca pemahaman dan minat belajar secara bersama-sama terhadap kemampuan menulis cerita pendek siswa SMP Swasta di Kabupaten Tangerang; Pengaruh kemampuan membaca pemahaman terhadap kemampuan menulis cerita pendek siswa SMP Swasta di Kabupaten Tangerang; Pengaruh minat terhadap kemampuan menulis cerita pendek siswa SMP Swasta di Kabupaten Tangerang?

\section{Landasan Teori}

\section{Hakikat Kemampuan Membaca Pemahaman}

Membaca pemahaman (reading comprehension) bertujuan untuk memahami standar atau norma kesastraan (literary standards), resensi kritis (critical 
review), dan pola-pola fiksi (patterns of fiction). Orang dengan intensitas membanya yang tinggi akan banyak menyerap pengetahuan dan pengalaman. Dengan banyaknya pengetahuan, maka akan banyak ide atau gagasan yang akan dituangkan dalam bentuk berbicara, maupun menulis dengan mudah.

Kegiatan membaca akan menghasilkan atau menemukan ide atau gagasan yang ada dalam bacaan tersebut dengan cepat, walaupun membacanya tidak secara detail. Menurut Kamus Besar Bahasa Indonesia (Departemen Pendidikan Indonesia, 2008) membaca adalah turunan dari kata dasar baca yang mendapat imbuhan mem, yang artinya. 1) melihat serta memahami isi dari apa yang tertulis (dengan melisankan atau hanya dalam hati): dia jangan diganggu, karena sedang membaca buku; 2) mengeja atau melafalkan apa yang tertulis; 3) mengucapkan: doa, - mantra, dan seterusnya.

Pemahaman adalah turunan dari kata paham yang artinya: proses, cara, perbuatan memahami atau memahamkan: bahasa sumber dan bahasa sasaran sangat penting bagi penerjemah. (Departemen Pendidikan Indonesia, 2008). Jadi, membaca pemahaman adalah perbuatan seseorang, melihat yang tertulis sebagai proses untuk memahami.

Menurut (Ahuja \& Ahuja, 2010) berpendapat membaca pemahaman adalah sebuah kemampuan yang diperlukan bagi orang yang mau mencari informasi dari teks tertulis. Selain itu, membaca juga sebagai alat untuk belajar. Jadi, membaca merupakan proses belajar.

Jadi, berdasarkan pendapat-pendapat di atas, membaca pemahan adalah kemampuan merekonstruksi pesan dalam teks dan menghubungkan pengetahuan yang dimiliki pembaca guna memahami informasi, ide atau gagasan, dan detail penting secara tepat. Jadi, membaca merupakan usaha untuk memahami sebuah bacaan dengan sebaik-baiknya. Jika teks disampaikan dengan cara dilafalkan, maka akan jelas dan fasih, tepat informasi dan penjedaannya, sehingga komunikatif dengan pendengar, dan juga ditandai oleh suatu pemahaman teks (Amir \& Slamet, 1996).

\section{Hakikat Minat Belajar}

Minat adalah kecenderungan hati yang tinggi terhadap sesuatu, gairah, keinginan (Departemen Pendidikan Indonesia, 2008). Belajar menurut KBBI (Departemen Pendidikan Indonesia, 2008) adalah hasil turunan dari kata dasar ajar yang artinya petunjuk yang diberikan kepada orang supaya diketahui (diturut) belajar berusaha memperoleh kepandaian atau ilmu: adik - membaca, berlatih: ia Sedang mengetik; murid-murid itu sedang - karate, berubah tingkah laku atau tanggapan yang disebabkan oleh pengalaman; dan seterusnya. Jadi, berdasarkan rincian di atas, belajar merupakan usaha untuk memperoleh kepandaian atau ilmu.

Setia orang tentunya mempunyai minat yang beragam atau tidak tetap. Ada beberapa usaha untuk menumbuhkan minat, salah satunya dengan AMBAK (Apa Manfaat Bagi Ku?). AMBAK adalah motivasi yang didapat dari pemilihan secara mental antara manfaat dan akibat-akibat suatu keputusan. Dengan AMBAk, dituntuk untuk mencari cara atau menemukan bahwa sesuatu itu dapat berguna atau bermanfaat untuk diri sendir. Dengan begitu motivasi untuk merealisasikan sesuatu 
tersebut sangat kuat (DePorter \& Hernacki, 2001). Dengan resep ini mudahmudahan dapat membuat minat dan menemukan cara belajar.

Menurut (Mahud, 1982) minat adalah kekuatan pendorong seseorang untuk menaruh perhatian pada situasi atau aktivitas tertentu. Berdasarkan definisi minat tersebut mengandung unsur-unsur sebagai berikut:

1) Minat adalah suatu gejala psikologis.

2) Adanya pemusatan perhatian, perasaaa dan pikiran dari subjek karena tertarik.

3) Adanya perasaan senang terhadap objek yang menjadi sasaran.

4) Adanya kemauan atau kecenderungan pada diri subjek untuk melakukan kegiatan guna mencapai tujuan.

Jadi, mengacu pada pendapat di atas, minat adalah gejala psikologis yang ditunjukan dengan adanya pengertian subjek terhadap objek karena adanya perhatian dan perasaaan senang.

\section{Definisi Belajar}

Belajar dapat didefinisikan suatu proses perubahan tingkah laku individu melalui interaksi dengan lingkungan. Menurut (Pemar, 2001) belajar merupakan suatu kegiatan, bukan hasil. Hasil belajar itu adalah perubahan tingkah laku, sedang kegiatan belajar merupakan upaya untuk mengubah hal tersebut. Oleh sebab itu, untuk mengubah tingkah laku yang baik diperlukan sebuah usaha yang dinamakan belajar dengan kualitas mutu terbaik.

Menurut (Gagne, 1985) belajar didefinisikan sebagai proses di mana suatu organisme berubah perilakunya akibat suatu pengalamar, Menurut James O. Wittaker, "learning may be defined as the process by which behavior organites or is altered through training or experience". Belajar dapat didefinisikan sebagai proses di mana tingkah laku ditimbulkan atau diubah melalui latihan atau pengalaman.

Menurut (Kingsley, Howard, \& Garry, 1957) mengatakan "learning is the process by which behavior (in the broader sense) is organited or changed through practice or training". Belajar adalah proses di mana tingkah laku ditimbulkan atau diubah melalui praktik atau latihan.

\section{Hakikat Kemampuan Menulis}

Ketika seseorang sedang menulis, penulis harus berkonsentrasi dengan semua keterampilan berbahasa dimiliki, agar tulisan berkualitas. Menurut (Tarigan, 1986), menulis adalah kegiatan menuangkan ide/gagasan dengan bahasa tulis sebagai media penyampai. Menurut (Semi, 2007), menulis merupakan suatu proses kreatif memindahkan gagasan ke dalam lambing-lambang tulisan.

Bepikir dalam proses menulis merupakan bentuk perhatian pada pembaca tertentu dan waktu tertentu.Berpikir juga akan menolong penulis untuk mencapai tujuannya. Intinya, dalam proses menulis menghasilkan penemuan, susunan, dan gaya. Secara singkat belajar menulis adalah belajar berpikir dalam/dengan cara tertentu (D’Angelo, 1980). 


\section{Hakikat Cerita Pendek}

Cerita pendek atau kisahan pendek (kurang dari 10.000 kata) yang memberikan kesan tunggal yang dominan dan memusatkan diri pada satu tokoh dalam satu situasi (pada suatu ketika) (Departemen Pendidikan Indonesia, 2008). Short story/cerita pendek: sebuah fiksi prosa pendek yang biasanya menggambarkan konflik tunggal (tidak seperti novel). Cerita pendek merupakan sebuah bentuk baru dari novel yang berasal dari awal abad kesembilan belas.

Menurut (Eneste, 2009) hampir sama dengan pengertian cerita pendek di atas yaitu sebagai berikut: Kisahan pendek, yang jumlah kata-katanya kurang dari 10.000 kata dengan memberikan kesan tunggal yang dominan dan memusatkan diri pada satu tokoh dalam satu situasi pada suatu ketika). Cerita pendek termasuk dalam hasil karya sastra, yang dapat kita bagi menjadi tiga macam, yaitu prosa, puisi, dan drama. Novel, novelet dan cerpen termasuk ke dalam prosa.

Dari beberapa pengertian tentang kemampuan, tentang menulis, dan tentang cerita pendek, penulis mencoba menyimpulkan apa yang dimaksud dengan kemampuan menulis cerita pendek yaitu seseorang yang dapat menulis atau mengarang sebuah cerita tentang perbuatan, pengalaman, atau penderitaan orang; kejadian-kejadian dan lain sebagainya; baik yang sungguh-sungguh terjadi atau yang hanya rekaan belaka, yang panjangnya kurang dari 10.000 kata, tetapi tidak kurang dari 7.500 kata yang bisa dibaca satu kali duduk.

Adapun hipotesis dalam penelitian ini adalah terdapat pengaruh yang signifikan kemampuan membaca pemahaman dan minat belajar secara bersamasama terhadap kemampuan menulis cerita pendek, terdapat pengaruh yang signifikan kemampuan membaca pemahaman terhadap kemampuan menulis cerita pendek, dan terdapat pengaruh yang signifikan minat belajar terhadap kemampuan menulis cerita pendek.

\section{METODE}

Untuk menunjukkan bahwa hipotesis penelitian yang telah ditetapkan benar adanya, digunakan metode penelitian survei deskriptif. Survei deskriptif merupakan metode penelitian tentang pengambilan sampel dari populasi dan menggunakan kuesioner dalam mengumpulkan data (Adkon \& Ridwan, 2009). Kuesioner terbentuk dari kumpulan pertanyaan tertulis yang bertujuan untuk memperoleh informasi dari responden (Arikunto, 2006). Data dari hasil kuesioner kemudian dianalisis secara deskriptif.

Penelitian dengan menggunakan teknik pengumpulan data survei adalah usaha untuk mendapatkan atau mengumpulkan informasi dari masalah-masalah tertentu. Data survei nantinya akan digunakan dalam penelitian untuk membuat deskripsi, gambaran atau lukisan secara sistematik, faktual dan akurat mengenai fakta-fakta serta hubungan antara fenomena yang diselidiki yaitu pengaruh kemampuan membaca pemahaman dan minat belajar terhadap kemampuan menulis cerita pendek bahasa Indonesia. 


\section{Diskursus: Jurnal Pendidikan Bahasa Indonesia}

Vol. 1, No. 2, Agustus 2018, pp. 178-187

p-ISSN: 2615-4935

e-ISSN: 2615-4943

\section{HASIL DAN PEMBAHASAN}

\section{Hasil}

Dari pengujian hipotesis yang dibantu dengan program SPSS versi 2.0 dihasilkan data sebagai berikut

Tabel 1. Hasil Perhitungan Pengujian Koefisien Korelasi Ganda Variabel $\mathrm{X}_{1}$ Model Summary

\begin{tabular}{|l|r|r|r|r|}
\hline Model & $\mathrm{R}$ & R Square & $\begin{array}{c}\text { Adjusted R } \\
\text { Square }\end{array}$ & $\begin{array}{c}\text { Std. Error of } \\
\text { the Estimate }\end{array}$ \\
\hline 1 & $.360^{\mathrm{a}}$ & .130 & .107 & 9.387 \\
\hline
\end{tabular}

a. Predictors: (Constant), Minat belajar, Membaca pemahaman

Tabel 2. Hasil Perhitungan Pengujian Signifikansi Koefisien Regresi Variabel $X_{1}$ dan $X_{2}$ terhadap $Y$

ANOVA $^{a}$

\begin{tabular}{|ll|r|r|r|r|r|}
\hline \multicolumn{1}{|l|}{} & \multicolumn{1}{c|}{$\begin{array}{l}\text { Sum of } \\
\text { Squares }\end{array}$} & df & Mean Square & F & Sig. \\
\hline 1 & Regression & 1012.244 & 2 & 506.122 & 5.744 & $.005^{\mathrm{b}}$ \\
& Residual & 6785.244 & 77 & 88.120 & & \\
& Total & 7797.488 & 79 & & & \\
\hline
\end{tabular}

a. Dependent Variable: Kemampuan menulis cerita pendek

b. Predictors: (Constant), Minat belajar, Membaca pemahaman

Coefficients $^{a}$

\begin{tabular}{|c|c|c|c|c|c|c|}
\hline \multirow{2}{*}{\multicolumn{2}{|c|}{ Model }} & \multicolumn{2}{|c|}{ Unstandardized Coefficients } & \multirow{2}{*}{$\begin{array}{c}\begin{array}{c}\text { Standardized } \\
\text { Coefficients }\end{array} \\
\text { Beta }\end{array}$} & \multirow[b]{2}{*}{$\mathrm{t}$} & \multirow[b]{2}{*}{ Sig. } \\
\hline & & $\mathrm{B}$ & Std. Error & & & \\
\hline \multirow[t]{3}{*}{1} & (Constant) & 13.905 & 21.419 & & .649 & .518 \\
\hline & Membaca pemahaman & .320 & .121 & .283 & 2.645 & .010 \\
\hline & Minat belajar & .368 & .154 & .255 & 2.387 & .019 \\
\hline
\end{tabular}

a. Dependent Variable: Kemampuan menulis cerita pendek

1. Pengaruh kemampuan membaca pemahaman $\left(X_{I}\right)$ dan minat belajar $\left(X_{2}\right)$ secara bersama-sama terhadap kemampuan menulis cerita pendek (Y).

Hipotesis yang diuji:

Ho: $\beta y_{1}=\beta y_{2}=0$

$H_{1}: \beta y_{1} \neq 0, \beta y_{2}=0$

Artinya:

Ho: tidak terdapat pengaruh kemampuan membaca pemahaman dan minat belajar secara bersama-sama terhadap kemampuan menulis cerita pendek. $\mathrm{H}_{1}$ : terdapat pengaruh kemampuan membaca pemahaman dan minat belajar 
secara bersama-sama terhadap kemampuan menulis cerita pendek.

Dari tabel di atas dapat dinyatakan bahwa terdapat pengaruh yang signifikan kemampuan membaca pemahaman dan minat belajar secara bersama-sama terhadap kemampuan menulis cerita pendek. Hal ini dibuktikan dengan perolehan nilai Sig. 0,005 $<0,05$ dan $F_{\text {hitung }}=5,744$.

Sementara itu, persamaan garis regresi ganda dapat dinyatakan dengan $\hat{Y}=13,905+0,320 \mathrm{X}_{\mathrm{I}}+0,368 \mathrm{X}_{2}$. Hal ini memiliki pengertian bahwa kenaikan skor variable kemampuan membaca pemahaman dan minat belajar memberikan kontribusi sebesar 0,320 oleh $X_{1}$ dan 0,368 oleh $X_{2}$ terhadap variabel kemampuan menulis cerita pendek Dari tabel di atas juga menjelaskan bahwa secara bersama-sama variabel kemampuan membaca pemahaman dan minat belajar memberikan kontribusi sebesar $13 \%$ terhadap variabel kemampuan menulis cerita pendek.

2. Pengaruh kemampuan membaca pemahaman $\left(X_{1}\right)$ terhadap Kemampuan menulis cerita pendek (Y).

Hipotesis yang diuji:

$H_{0}: \beta y_{1}=0$

$H_{1}: \beta y_{1} \neq 0$

Artinya:

$\mathrm{H}_{0}$ : tidak terdapat pengaruh kemampuan membaca pemahaman terhadap kemampuan menulis cerita pendek

$\mathrm{H}_{1}$ : terdapat pengaruh kemampuan membaca pemahaman terhadap kemampuan menulis cerita pendek.

Dari table di atas dapat dinyatakan bahwa terdapat pengaruh yang signifikan kemampuan membaca pemahaman terhadap kemampuan menulis cerita pendek. Hal ini dibuktikan dengan perolehan nilai Sig. 0,010 < 0,05 dan $\mathrm{t}_{\text {hitung }}=2,645$.

Adapun kontribusi variabel kemampuan membaca pemahaman terhadap kemampuan menulis cerita pendek dapat dinyatakan dengan rumus: $\mathrm{KD}=$ Nilai $\beta_{X I Y} \mathrm{X}$ Nilai Korelasi Pasialnya $\left(r_{X I Y}\right) \mathrm{X} 100 \% \mathrm{KD}=-0,283$ X $-0,256$ X $100 \%=7,24 \%$

Dari hasil perhitungan di atas dapat dinyatakan bahwa kontribusi kemampuan membaca pemahaman dalam meningkatkan kemampuan menulis cerita pendek sebesar 7,24\%

3. Pengaruh minat belajar (X2) terhadap kemampuan menulis cerita pendek (Y). Hipotesis yang diuji:

Ho: $\beta_{y l}=0$

$H i: \beta_{y 1} \neq 0$

Artinya:

Ho: tidak terdapat pengaruh minat belajar terhadap kemampuan menulis cerita 
pendek.

$\mathrm{H}_{1}$ : terdapat pengaruh minat belajar terhadap kemampuan menulis cerita pendek.

Dari tabel di atas dapat dinyatakan bahwa terdapat pengaruh yang signifikan minat belajar terhadap kemampuan menulis cerita pendek. Hal ini dibuktikan dengan perolehan nilai Sig. 0,019<0,05 dan thitung $=2,387$. Adapun kontribusi variabel minat belajar terhadap kemampuan menulis cerita pendek dinyatakan dengan rumus:

$\mathrm{KD}=$ Nilai $\beta_{X 2 Y} \mathrm{X}$ Nilai Korelasi Pasialnya $\left(r_{x 2 y}\right) \mathrm{X} 100 \%$

$\mathrm{KD}=0,255 \times 0,225 \times 100 \%=5,74 \%$

Dari hasil perhitungan di atas dapat dinyatakan bahwa kontribusi minat belajar dalam meningkatkan kemampuan menulis cerita pendek sebesar 5,74\%

\section{Pembahasan}

1. Pengaruh kemampuan membaca pemahaman $\left(X_{1}\right)$ dan minat belajar $\left(X_{2}\right)$ secara bersama-sama terhadap kemampuan menulis cerita pendek (Y)

Hasil penelitian di atas menyimpulkan bahwa kemampuan membaca pemahaman dan minat belajar secara bersama-sama telah memberikan pengaruh positif terhadap peningkatan kemampuan menulis cerita pendek. Hal ini mengandung arti bahwa kemampuan membaca pemahaman dan minat belajar telah memberikan pengaruh yang signifikan terhadap peningkatan kemampuan menulis cerita pendek siswa SMP Swasta Kabupaten Tangerang.

Kemampuan membaca pemahaman merupakan modal dasar bagi semua siswa dalam mengembangkan ilmu dan pengetahuannya. Dalam penelitian ini ternyata faktor kemampuan membaca pemahaman lebih dominan dibanding minat belajar terhadap kemampuan menulis cerita pendek. Peran kemampuan membaca pemahaman terhadap kemampuan menulis cerita pendek menunjukkan pentingnya seorang siswa untuk banyak membaca. Dengan kemampuan membaca pemahaman banyak informasi yang siswa dapatkan termasuk contoh karangan cerita pendek yang benar dan baik. Dengan kemampuan membaca pemahaman iniliah seorang siswa dapat mengembangkan kemampuan menulis cerita pendek.

Selain kemampuan membaca pemahaman, faktor lain yang dapat mempengaruhi kemampuan menulis cerita pendek adalah minat belajar. Minat belajar menulis cerita pendek yang tinggi akan memengaruhi upaya siswa dalam menguasai kaidah-kaidah penulisan cerita pendek. Kaitannya dengan kemampuan membaca pemahaman, guru harus berupaya memberi pelatihan yang mengarah kepada kemampuan membaca pemahaman. Dengan dimiliki kedua variabel ini maka kemampuan menulis cerita pendek tercapai.

\section{Pengaruh kemampuan membaca pemahaman (X1) terhadap kemampuan} menulis cerita pendek ( $Y$ )

Dari hasil penelitian dan teori yang ada dapat disimpulkan bahwa kemampuan membaca pemahaman telah memberikan pengaruh positif terhadap peningkatan 
kemampuan menulis cerita pendek siswa SMP Swasta kabupaten Tangerrang. Artinya, adanya kemampuan membaca pemahaman telah memberikan kontribusi dalam menulis cerita pendek.

Kemampuan membaca pemahaman yang siswa dapatkan tidak hanya mendorong mereka untuk mengetahui makna harafiah dari kata tersesebut (makna yang didapat dari kamus), tetapi juga mampu mengenal, memahami, dan menggunakan kata-kata dengan baik dan benar pada kegiatan mendengar, berbicara, dan menulis. Dengan demikian, siswa yang kemampuan membaca pemahamannya cukup akan memudahkan dalam melatih menulis cerita pendek.

Uraian di atas menjelaskan bahwa kemampuan membaca pemahaman adalah kemampuan seseorang untuk mengenal, memahami, suatu bacaan dengan baik. Memahami suatu bacaan akan memperoleh informasi dan pengetahuan baru. Selanjutnya, hakikat memahami bacaan adalah memperoleh model tulisan cerita pendek yang memungkinkan siswa untuk meniru format cerita yang telah mereka baca.

\section{Pengaruh minat belajar $\left(\mathrm{X}_{1}\right)$ terhadap kemampuan menulis cerita pendek} (Y).

Hasil penelitian menunjukkan bahwa minat belajar menulis cerita pendek siswa telah memberikan pengaruh positif terhadap kemampuan menulis cerita pendek siswa SMP Swasta Kabupaten Tangerang. Artinya, minat belajar yang tinggi dapat memberikan pengaruh yang signifikan terhadap kemampuan menulis cerita pendek siswa SMP Swasta Kabupaten Tangerang.

Paradigma lama guru mengajarkan bersumber pada teori asumsi tabula rasa, yang mengatakan bahwa pikiran seorang anak ibarat kertas putih yang masih kosong, bersih belum ada coretan, tentu yang akan menulisi kertas kosong tersebut adalah orang tua ataupun gurunya. Akibat asumsi ini banyak guru yang melakukan pembelajaran memindahkan pengetahuan dari guru kepada murid atau istilahnya transfer ilmu, dampak lain guru kurang menanamkan nilai-nilai luhur, etika, moral, akhlak dan agama, sehingga menciptakan anak pintar, tetapi kurang baik akhlak dan budi pekertinya. Penyebab lain di antaranya kurangnya minat belajar dari siswa itu sendiri sehingga keterampilan berbahasa Indonesia menjadi rendah. Dalam kamus ilmiah populer dijelaskan bahwa kata minat berarti dorongan, alasan tujuan tindakan.

Minat sangat besar pengaruhnya bagi proses menulis cerita pendek dan harus ada di dalam dirinya karena minat merupakan modal yang sangat mendasar untuk mencapai tujuan. Dengan demikian, minat merupakan permulaan dari setiap aktivitas. Jelas bahwa seorang siswa yang memiliki minat belajar tinggi berarti memiliki keinginan yang tinggi pula dalam meraih sesuatu. Dalam hal menulis cerita pendek, seorang siswa akan memperhatikan pengetahuan yang ia pelajari secara konsisten dengan rasa senang.

\section{SIMPULAN}

Dari pembahasan dan hasil penelitian dapat disimpulkan sebagai berikut: 
1. Terdapat pengaruh yang signifikan kemampuan membaca pemahaman dan minat belajar secara bersama-sama terhadap peningkatan kemampuan menulis cerita pendek. Hal ini dibuktikan dengan perolehan nilai Sig. 0,005 $<0,05$ dan $F_{\text {hitung }}=5,744$. Secara bersama-sama variabel kemampuan membaca pemahaman dan minat belajat memberikan kontribusi sebesar $13 \%$ terhadap variabel kemampuan menulis cerita pendek.

2. Terdapat pengaruh yang signifikan kemampuan membaca pemahaman terhadap kemampuan menulis cerita pendek. Hal ini dibuktikan dengan perolehan nilai Sig. $0,010<0,05$ dan thitung $=2,645$. Kontribusi yang diberikan variabel membaca pemahaman terhadap kemampuan menulis cerita pendek sebesar $7,24 \%$.

3. Terdapat pengaruh yang signifikan minat belajar terhadap kemampuan menulis cerita pendek. Hal ini dibuktikan dengan perolehan nilai Sig. 0,019<0,05 dan $t_{\text {hitung }}=2,387$. Variabel minat belajar ini memberikan kontribusi dalam meningkatkan kemampuan menulis cerita pendek sebesar 5,74\%

\section{DAFTAR PUSTAKA}

Adkon, \& Ridwan. (2009). Rumus dan data dalam analisis statistik untuk penelitian (Cetakan 3). Bandung: Alfabeta.

Ahuja, P., \& Ahuja, G. C. (2010). Membaca Secara Efektif dan Efisien. In Bandung: Kiblat Buku Utama. Bandung: Kiblat Buku Utama.

Amir, \& Slamet, Y. (1996). Peningkatan keterampilan berbahasa Indonesia (Bahasa lisan dan bahasa tertulis). Surakarta: Universitas Sebelas Maret.

Arikunto, S. (2006). Prosedur penelitian suatu pendekatan praktik. Jakarta: Rineka Cipta.

D'Angelo, F. J. (1980). Process and thought in composition. Massa-Chusetts: Winthrop Publisher. Inc.

Departemen Pendidikan Indonesia. (2008). Kamus besar bahasa Indonesia. Jakarta: Balai Pustaka.

DePorter, B., \& Hernacki, M. (2001). Quantum learning. Membiasakan belajar nyaman dan menyenangkan. Bandung: Kaifa.

Eneste, P. (2009). Buku pintar penyuntingan naskah. Jakarta: Gramedia Pustaka Utama.

Gagne, E. D. (1985). The cognitive psychology of school learning. Boston: Little, Brown and Company.

Kingsley, L., Howard, \& Garry, R. (1957). The nature and condition of learning. N.J. Practice Hall, Inc, Engliwood Clifts.

Mahud, D. (1982). Psikologi pendidikan: Suatu pendekatan (Jilid II). Yogyakarta: Rake Press.

Pemar, H. (2001). Proses belajar mengajar. Bandung: PT Remaja Rosda Karya. Semi, M. A. (2007). Dasar-dasar keterampilan menulis. Bandung: Angkasa.

Tarigan, H. G. (1986). Menulis sebagai suatu keterampilan berbahasa. Bandung: Angkasa. 